\title{
WPS3494
}

\section{Small-Scale Irrigation Dams, Agricultural Production, and Health: Theory and Evidence from Ethiopia}

\author{
Lire Ersado \\ The World Bank
}

\begin{abstract}
World Bank Policy Research Working Paper 3494, January 2005
The Policy Research Working Paper Series disseminates the findings of work in progress to encourage the exchange of ideas about development issues. An objective of the series is to get the findings out quickly, even if the presentations are less than fully polished. The papers carry the names of the authors and should be cited accordingly. The findings, interpretations, and conclusions expressed in this paper are entirely those of the authors. They do not necessarily represent the view of the World Bank, its Executive Directors, or the countries they represent. Policy Research Working Papers are available online at http://econ.worldbank.org.
\end{abstract}

I would like to thank Gregory S. Amacher, Associate Professor, Virginia Tech, Derek Byerlee, The World Bank, and the participants of a Policy Forum jointly sponsored by the Ethiopian Development Research Institute (EDRI) and International Food Policy Research Institute (IFPRI) on the State of Food Security and Agricultural Marketing in Ethiopia, May 15-16 2003, Addis Ababa, Ethiopia and Adugna Debessa of the Ministry of Water Resources for valuable comments on an earlier version of the paper.

Address all correspondence to Lire Ersado, 1818 H St NW, MSN: H4-405, Washington, DC 20433; Email: lersado@worldbank.org; Phone: (202) 473-2377/ Fax: (202) 522-2754. 


\begin{abstract}
This paper looks at the feasibility and potential of instituting small-scale irrigation dams to reduce Ethiopia's dependence on rainfed agriculture and the associated food insecurity. It develops a theoretical framework to assess the welfare implications of irrigation development programs and provides some empirical evidence from microdam construction and reforestation projects in northern Ethiopia. The paper pays particular attention to health-related costs of establishing small-scale irrigation dams in areas prone to waterborne diseases. While the theoretical analyses imply that the net welfare impacts of irrigation dams cannot be known a priori due to potential health costs, the empirical evidence shows that current agricultural yield and farm profit have increased in villages with closer proximity to the dams than in those more distant. The increased disease incidence due to standing pools of water has, however, led to significant declines in the returns from investment in irrigation water. Households with poor health are less likely to adopt productivity-enhancing as well as resource-conserving technologies, which are crucial for achieving the ultimate goal of sustainable agricultural development. The ensuing sickness has also led to reduction in labor allocation to off-farm activities. The findings underline the importance of weighing beforehand the magnitude of potential economic benefits against health costs of water development programs. The overall evidence, however, suggests that carefully designed irrigation dams could significantly improve agricultural production and food security, particularly in areas where waterborne diseases pose negligible risk to health or can be cost-effectively controlled.
\end{abstract}




\section{Introduction}

Successful agricultural development has resulted in a significant reduction of poverty and an improvement in food security in most developing countries of Asia and Latin America.

However, in many parts of Sub-Saharan Africa, despite numerous macroeconomic, political, and sectoral reforms, poverty, environmental degradation and food insecurity appear to be on the rise. There is a pressing need for Sub-Saharan African countries to increase agricultural productivity while pursuing sustainable management of their natural resource base on which food production depends. Such development efforts require significant public investments in agricultural and environmental resources development, often with financial support from external sources. Currently, the need to increase agricultural productivity and attain food security is nowhere more pressing than in Ethiopia, which has become a typical case of recurring famines and food insecurity, and is a major recipient of foreign food aid.

Agriculture, as in many other developing countries, is the mainstay of Ethiopia's economy, providing the livelihood base for nearly $85 \%$ of the population, contributing over $50 \%$ of gross domestic product, and accounting for about $90 \%$ of foreign exchange earnings. Many would concur that the overall performance of Ethiopia's economy for the foreseeable future to a great extent depends on the developments in this sector. The lack of sustained economic growth and emergent food crises in the country now and in the past are the results of weak transformation of the agricultural sector. These conditions are buttressed by high population growth, environmental degradation, and poor market and institutional arrangements. For much of the last three decades, food production has lagged population growth and the natural resources base on which agriculture depends has eroded at an alarming rate, further depressing the sector's productivity and increasing the poverty and vulnerability of the population. 
Ethiopian agriculture is largely small-scale, subsistence-oriented, and crucially dependent on rainfall. The highlands of Ethiopia, which house most of the country's agricultural potential, suffer from massive land degradation due to soil erosion caused by heavy runoff and deforestation, and the low productivity of peasant agriculture. ${ }^{1}$ The increasing loss of soil and other natural resources has resulted in steady declines in land and labor productivity (FAO, 1986; Hurni, 1993; Shiferaw and Holden, 1999). Despite a renewed emphasis currently being given to agriculture, the country continues to face difficulty in meeting the food consumption needs of its population.

Dependence on rainfed agriculture coupled with the erratic nature of rainfall is one of the main causes of widespread food insecurity in the country. Droughts occur every 3-5 years in northern Ethiopia and every 8-10 years for the whole country, with severe consequences for food production (Haile, 1988). With the lack of well-functioning social networks to provide safeguards at the local, regional or national levels, it is prohibitively difficult to survive even a single year of failed harvest. Hence a sustainable increase in food production to achieve selfsufficiency depends, at least in part, on how Ethiopia addresses its dependence on rainfall.

The government of Ethiopia, as stated in its Poverty Reduction Strategy Paper (PRSP), has recognized the importance of water and increased its focus on water resource development and utilization to achieve food security (FDRE, 2000). Its water policy stresses increased use of small-scale irrigation through diversion of rivers and building of small dams. Effective implementation of such programs however requires a comprehensive analysis of the immediate and potential benefits as well as the direct and indirect costs to the intended beneficiaries.

\footnotetext{
${ }^{1}$ Grepperud (1996) shows that, under comparable physical conditions, heavy degradations of land in Ethiopia occur in highly populated areas.
} 
Critical analyses under various agro-ecological zones of the feasibility, benefits and costs of instituting small-scale irrigation dams have been lacking. This paper was motivated to contribute to this aspect of public investment in water development projects.

The paper aims to develop a theoretical framework for better understanding of the economic impact of irrigation water development programs. Particular emphasis is given to the health impacts of establishing small-scale irrigation dams in drought and waterborne diseaseprone areas. It brings empirical evidence from the microdam construction and reforestation activities of the Sustainable Agricultural and Environmental Rehabilitation (SAERT) program in the northern Ethiopia regional state of Tigray. The paper examines the potential and significance of small-scale irrigation dams for enhancing agricultural productivity and the welfare of farm households from a couple of directions. First, it examines their impacts on household agricultural production and labor allocation decision-making. Second, it looks at the impact on the health of people and the adoption of productivity-enhancing and resource-conserving technologies complementary to irrigation agriculture. Third, it examines the impact of the project on non-farm activities and income diversification. Finally, it quantifies the net benefits of projects in terms of production and consumption gains against health costs. The findings could assist policymakers in their assessment of the potential and significance of constructing small-scale dams for irrigation purposes. We draw lessons for similar interventions in other parts of the country.

\section{Microdam Construction in Tigray, Ethiopia}

Tigray is one of the most land-degraded states of Ethiopia (Hurni, 1993). The region is characterized by subsistence farm households raising predominantly cereal and vegetable crops for local consumption and sale. Crop production in the region has failed to keep pace with 
population growth due to recurrent droughts, environmental degradation, and wars, including the most recent conflict with Eritrea. In response to severe environmental degradation and population-resource imbalance, the government of Ethiopia has initiated a major rural development program called SAERT (Sustainable Agricultural and Environmental Rehabilitation) through which several small dams have been constructed. The water development program is intended to rehabilitate degraded environments, enhance the adoption of irrigation practices, and ultimately increase agricultural productivity and sustainability (MUC, 1994; Ersado, et al., 2004).

Well-designed and constructed small water bodies such as microdams can have multiple benefits for their surrounding communities. Beyond making water available for the irrigation of field crops, microdams may provide water for garden cultivation, trees and other vegetation, and water for cattle. Other productive uses may include fishing and harvesting aquatic plants and animals. In developing countries, where water is scarce, these permanent water bodies could also be a major domestic source of water for drinking and other household uses. In addition, microdams could have beneficial environmental functions through improving plant and animal biodiversity and reducing soil erosion and degradation. Such multiple uses have favorable implications for the construction of small water bodies in regions where rainfall is unpredictable and the climate is arid to semiarid.

However, microdam creation in Tigray is associated with important health side effects. There are concerns that these new sources of water may have increased the prevalence of waterborne diseases such as malaria and schistosomiasis (Ersado et al., 2004; MUC, 1994). Malaria and schistosomiasis have historically been present in Tigray, but only seasonally during the rainy months. The presence of microdams has increased the prevalence of these ailments 
during the other seasons, as standing water provides a favorable environment for disease transmission (MUC, 1994; Amacher et al., 2004; Lampietti, 1999). Both diseases are debilitating and, if contracted, will seriously affect a person's ability to work, resulting in lower productivity, more household time and resources devoted to taking care of sick family members, as well as increases in medical expenses. Sickness and malnutrition keep children out of school, potentially imparting a long-lasting negative impact on the welfare of the region's population.

\section{Data and Descriptive Analysis}

The data come from a World Health Organization (WHO) sponsored research project undertaken by the authors in cooperation with Mekele University and the Tigray Health Bureau during one major cropping season in 1996/1997. The survey involved a three-stage sampling design. In the first stage, adjacent districts from three zones in Tigray regional state were chosen based on the availability of microdams. In the second stage, villages were chosen in each district, based on the proximity to microdams, the reported incidence of malaria, and elevation. Eight public microdams and 29 surrounding villages were included in the sample. Fifteen of the 29 villages were classified as intervention groups due to their close proximity to microdam and irrigation water. The intervention villages are within 3 kilometers of a nearby microdam. The control villages are about 8-10 kilometers away from the nearest microdam and assumed not to be affected. In the final stage, a sample of households was randomly chosen in each village. The villages were selected in such a way as to ensure that sufficient households from control villages and households with a wide range of accessibility to the microdams would be included in the sample. 
The survey contained a detailed list of questions on household production, consumption, expenditure, time use, adoption rate and time of adoption of different agricultural and forestry technologies. There was a list of questions on health, and number of days a household member was sick, as well as demographic and other characteristics important to household decisionmaking and preference. Table 1 shows the distribution of sampled households in the three zones and their proximity to irrigation microdams.

The descriptive statistics in Table 2 show that demographic and landownership variables are not appreciably different in intervention and control groups. However, average rainfall is significantly higher and mean altitude (above sea level) lower in the intervention villages. The malaria risk associated with microdams is greater in higher precipitation areas and at lower elevations. In the subsequent analyses, it is thus important to control for elevation and annual precipitation in order to disentangle the health effects of microdams from other effects.

\section{(a) Microdams and Technology Adoption}

Public investments in water development projects in Tigray are expected to encourage the adoption of productivity-enhancing and resource-conserving technologies complementary to irrigation use. Technologies complementary to irrigation agriculture such as high yielding varieties, soil conservation practices, planting multipurpose trees and others are essential for increasing the productivity and sustainability of agriculture. Evidence from the survey data indicates that there are higher adoption rates of these technologies in the intervention villages, compared to the control villages (see Table 3). Households in intervention areas are three times more likely to engage in irrigation technologies, and to adopt other technologies such as improved stoves, compared to those living in control villages. 
(b) Microdams, Labor Supply and Disease Incidence

The prevalence of disease is significantly higher in intervention villages. Malaria incidence is about $32 \%$ among households in microdam villages compared to only $19 \%$ in the control areas. A considerable amount of labor time is lost due to sickness. The average number of working days for adult males and females as well as children is lower in the intervention villages. Correspondingly, the number of days adult males and females are sick, productive time spent caring for sick family members, and medical expenses are higher in villages near microdams than in those more distant. The time household females spend staying home and taking care of sick family members in microdam villages is, on average, three times higher than that in control areas (see Table 4). Hired labor use by households is greater in intervention areas. Furthermore, households in intervention villages spend significantly less time in off-farm activities.

\section{(c) Household Incomes in Intervention Villages}

Average household income appears higher in the intervention villages where microdams are accessible. This is mainly because of higher income from agricultural production in the intervention villages, particularly from cereals. However these production gains are partially offset by higher expenditures on medical care and hiring outside labor. Incomes from nonfarm sources are lower in the intervention villages. This might suggest that, with nonfarm income shrinking and disease incidence increasing, households in close proximity to microdams may have become more vulnerable to the risk of, for instance, a failed harvest due to rain shortfalls. 


\section{Theoretical Model}

In this section, we present a conceptual framework underpinning a typical agricultural household decisionmaking model. While the framework is not new to the literature, the novelty in our approach is to add the health dimension to household time allocation, production and consumption decisions. We anticipate that health concerns impact market and nonmarket participation decisions, and these will lead to corresponding changes in household income, time allocation, and resource use in the study area. Microdams affect production directly through water and fuel provision, and indirectly through their impacts on health $(H) .^{2}$

Assume that a household produces two goods: agricultural crops and fuelwood products. While fuelwood is primarily collected for own consumption, any surplus of agricultural products not consumed is sold in a local market. Assume also that at the beginning of each season, the household has an endowment of land, $\bar{A}$. The household's joint production technology for the two goods is: ${ }^{3}$

$$
G\left(Q, F, L_{q}, L_{h d}, L_{f}, A, D ; H\right)=0
$$

where $Q$ is total agricultural production of cereals and vegetables, $F$ is total collection of fuelwood and agricultural residues, $L_{q}$ is household time allocated to agricultural production, $L_{h d}$ is hired labor used in agricultural production, $L_{f}$ is household time allocated to fuel collection, and $A$ is land allocated to agriculture that may be greater than or less than $\bar{A} \cdot{ }^{4} D$ is a vector of microdam characteristics variables (such as age of and distance to a nearest microdam).

\footnotetext{
${ }^{2}$ Please refer to appendices 1 and 2 for details on theoretical model and analysis.

${ }^{3}$ For simplicity of notation, other inputs in agricultural production and fuel collection such as environmental characteristics variables and access to input and output markets are not included in $G($.

${ }^{4}$ Since there is a land rental market in the study area, we treat agricultural land as a choice variable.
} 
Microdam affects production directly through water and fuel provision, and indirectly through its impacts on health $(H)$. Health affects the productivity of household inputs such as labor $\left(\partial Q / \partial L_{q} \partial H^{>0,} \partial F / \partial L_{f} \partial H^{>0}\right)$

Household's total labor time $(T)$ available is allocated into production and healthcare activities: ${ }^{5}$

$$
T=L_{f}+C_{h}+L_{q}
$$

$C_{h}$ is household time allocated to taking care of sick family members and childcare. Households with sick members will have less time for productive activities, not only because of time spent sick but also time spent away from work to care for sick family members. Household health thus affects production not only through its effect on the quality of own labor but also through reduction in labor availability.

Besides labor supply and production decisions, the household also makes consumption decisions on goods from own production or market purchase. Let $C_{m}$ be a composite vector of nonhousehold produced market purchased goods consumed by the household and $C_{q}$ be own agricultural products consumed, and $\mathrm{C}_{f}$ is fuelwood consumed. Given agricultural production $Q$, the quantity $\left(Q-C_{q}\right)$ represents market sales when positive or purchases when negative. Similarly the quantity $\left(F-C_{f}\right)$ represents market sales of fuelwood when positive or purchases when negative. Household consumption and time allocation into different productive and health-care activities also depends on household monetary constraints. Households face a cash budget constraint where income equals outlays for purchased goods, health-care services and hired labor expenditures:

\footnotetext{
${ }^{5}$ It is assumed that some fixed amount of time for household domestic chores and leisure is already subtracted from T or time for those activities is subsumed in $\mathrm{C}_{h}$.
} 


$$
p_{m} C_{m}+p_{h} C_{h c}+w L_{h d}=M+p_{q}\left(Q-C_{q}\right)+p_{f}\left(F-C_{f}\right)
$$

where $p_{m}$ is a price vector for nonfuel and noncrop goods, $C_{h c}$ is health-care services from local clinics or doctors such as medical treatment and transportation costs, $p_{h}$ is the unit price of health services, and $w$ is the market wage rate. $M$ is income from nonfarm and exogenous sources, $p_{q}$ is the price of agricultural produce and $p_{f}$ is the price of fuelwood.

Finally, the household produces health, which is hypothesized to be a function of proximity to microdam sites, and household consumption of goods and healthcare services: ${ }^{6}$

$$
H=H\left(C_{m}, C_{q}, C_{f}, C_{h c}, D\right)
$$

The household is assumed to maximize its utility from consumption of health, and of market purchased and own produced goods:

$$
U\left(H, C_{m}, C_{q}, C_{f}, C_{h c}\right)
$$

where $U\left(\right.$. ) is increasing in all arguments. ${ }^{7}$

The household decision-maker maximizes (5) subject to (1)-(4). The Lagrangian associated with the above constrained utility maximization problem is:

$$
\begin{aligned}
\mathrm{L}= & U\left(H(.), C_{m}, C_{q}, C_{f}, C_{h c}\right)+\eta[G(.)]+\mu\left[T-\left(L_{q}+L_{f}+C_{h}\right)\right] \\
& +\lambda\left[M+p_{q}\left(Q-C_{q}\right)+p_{f}\left(F-C_{f}\right)-\left(p_{m} C_{m}+p_{h} C_{h c}+w_{l} L_{h d}\right)\right]
\end{aligned}
$$

where $\lambda, \eta$, and $\mu$ are Lagrange multipliers associated with budget, production technology, and labor time constraints. $\lambda$ is also the marginal utility of income. Following de Janvry et al.

\footnotetext{
${ }^{6}$ Other individual, household and community characteristics that affect health such as quality of house and toilet, planting of certain species of trees believed to reduce the malarial threat, possession of improved heating and stoves, etc., are not included for the sake of simplicity.

${ }^{7}$ Inclusion of $H$ in the utility function follows Grossman (1972) in that we assume individual's health status affects utility both indirectly, through raising labor income, and directly, by assuming individuals value good health per se.
} 
(1991), the objective function can be simplified by redefining the budget constraint in terms of a profit function and associated shadow prices for nonmarket inputs and outputs:

$$
\left.\mathrm{L}=U\left(H(.), C_{m}, C_{q}, C_{f}, C_{h c}\right)+\lambda\left[Y-p_{q} C_{q}-p_{f} C_{f}-p_{m} C_{m}-p_{h} C_{h c}-w_{l} C_{h}\right)\right]
$$

where:

$$
\begin{aligned}
& w_{l}=\mu / \lambda \\
& Y=M+w_{l} T+\pi\left(p_{m}, p_{q}, p_{f}, w_{l}, D, H\right)
\end{aligned}
$$

and

$$
\begin{gathered}
\pi\left(p_{m}, p_{q}, p_{f}, w_{l}, D, H\right)=\operatorname{Max}_{L_{q}, L_{f}, L_{h d}, A}\left\{p_{f} F+p_{q} Q-w_{l}\left(L_{q}+L_{f}+L_{h d}\right)\right\} \\
\text { s.t. } G(.)=0
\end{gathered}
$$

Note that the shadow prices $w_{l}$ transform the Lagrange multipliers for time constraints into monetary values. $Y$ is total household income from household profits from agricultural and fuelwood collection activities, nonfarm incomes and the value of household's time endowment. Assuming interior solutions, the household's utility maximizing production, consumption and health-care choices can be defined:

$$
\begin{aligned}
& Q=Q\left(p_{m}, p_{f}, p_{q}, w_{l}, D, H\right) \\
& F=F\left(p_{m}, p_{f}, p_{q}, w_{l}, D, H\right) \\
& L_{i}=L_{i}\left(p_{m}, p_{f}, p_{q}, w_{l}, D, H\right) ; i=q, f, h d \\
& C_{h}=C_{h}\left(p_{m}, p_{q}, p_{f}, w_{l}, D, Y, H\right) \\
& C_{j}=C_{j}\left(p_{m}, p_{q}, p_{f}, w_{l}, Y, H\right) ; j=m, q, f, h c
\end{aligned}
$$

where the shadow wage $\left(w_{l}\right)$ is evaluated at the optimum. The optimal production choices in (11) through (14) have all the standard properties following profit maximization in prices $w_{l}, p_{f}$, and $p_{q}$. The utility maximizing choices (13) and (14) have all the standard properties in price and 
income from consumer theory. Therefore, own-compensated price effects are negative, crosscompensated price effects are symmetric, and so on.

\section{Comparative Static Analysis and Implications}

Since the main focus of the paper is on the economic analysis of microdam impacts, we employ comparative statics on the optimal production and consumption choices. Such analysis will allow us to examine the welfare impact of changes in access to a microdam and irrigation water. The framework developed above can be used to analyze the impact of access to microdams on the opportunity cost of household time $\left(w_{l}\right)$, agricultural yield $(Q)$, expenditure on health care $\left(C_{h c}\right)$, and other variables of policy interest. Recall that households with close proximity to microdams reported not only higher agricultural production but also increased waterborne disease incidences.

\section{(a) Impact on shadow price of time}

Assume the labor market is nonexistent (i.e., $L_{h d}=0$ ). Joint profit and utility maximization implies that labor "market" equilibrium holds:

$$
T-\left[L_{q}\left(p_{m}, p_{f}, p_{q}, w_{l}, D, H\right)+L_{f}\left(p_{m}, p_{f}, p_{q}, w_{l}, D, H\right)+C_{h}\left(p_{m}, p_{f}, p_{q}, w_{l}, Y, H\right)\right]=0
$$

where $p_{m}, p_{q}, p_{f}, D$, and $H$ are exogenous variables and $w_{l}, L_{i}(i=q, f, h)$ and $C_{h}$ are evaluated at the utility maximizing levels. Totally differentiating (15) with respect to $D$ and $w_{l}$ and using Envelope Theorem give:

$$
\frac{\partial w_{l}}{\partial D}=\frac{-\left[\frac{\partial C_{h}}{\partial Y} \frac{\partial \pi}{\partial D}+\frac{\partial C_{h}}{\partial H} \frac{\partial H}{\partial D}+\frac{\partial L_{q}}{\partial H} \frac{\partial H}{\partial D}+\frac{\partial L_{q}}{\partial D}+\frac{\partial L_{f}}{\partial H} \frac{\partial H}{\partial D}+\frac{\partial L_{f}}{\partial D}\right]}{\left[\frac{\partial C_{h}}{\partial w_{l}}+\frac{\partial C_{h}}{\partial Y}\left(T-L_{q}-L_{f}-L_{h d}\right)+\frac{\partial L_{q}}{\partial w_{l}}+\frac{\partial L_{f}}{\partial w_{l}}\right]}
$$


Equation (16) can be simplified since $C_{h}=\left(T-L_{q}-L_{f}\right), L_{h d}=0$, and consumer theory implies that the following Slutsky equation holds for a Hicksian demand $C_{h}^{*}$ :

$$
\frac{\partial C_{h}}{\partial w_{l}}=\frac{\partial C_{h}^{*}}{\partial w_{l}}-\frac{\partial C_{h}}{\partial Y} C_{h}
$$

Thus,

$$
\frac{\partial w_{l}}{\partial D}=\frac{-\left[\frac{\partial C_{h}}{\partial Y} \frac{\partial \pi}{\partial D}+\frac{\partial C_{h}}{\partial H} \frac{\partial H}{\partial D}+\frac{\partial L_{q}}{\partial H} \frac{\partial H}{\partial D}+\frac{\partial L_{q}}{\partial D}+\frac{\partial L_{f}}{\partial H} \frac{\partial H}{\partial D}+\frac{\partial L_{f}}{\partial D}\right]}{\left[\frac{\partial C_{h}^{*}}{\partial w_{l}}+\frac{\partial L_{q}}{\partial w_{l}}+\frac{\partial L_{f}}{\partial w_{l}}\right]}
$$

Using standard assumptions of utility and profit maximization, all terms in the denominator are negative: Hicksian own-price substitution effects are negative and profit maximizing input demands decline in own prices. With assumptions that time for caring for the sick is a normal good and access to microdams enhances farm profits, the first term in the numerator is positive. However, the remaining terms cannot be unambiguously signed. The response of agricultural and fuelwood collection labor supply to changes in access to microdams depends on whether the production effects outweigh consumption effects. In other words, if the negative impact of access to microdam on health does not exceed the profitability of farm production and collection, the sign of the numerator as a whole will be positive. If these conditions hold:

$$
\frac{\partial w_{l}}{\partial D}>0
$$

Therefore increased access to irrigation dams increases the shadow price of time and vice versa.

On the other hand, note that impact of health on shadow price is unambiguously positive. The seminal paper by Grossman (1972) shows that individuals invest in health production until the marginal cost of health production equaled the marginal benefits of improved health status. Using a similar approach as above: 


$$
\frac{\partial w_{l}}{\partial H}=\frac{-\left[\frac{\partial C_{h}}{\partial Y} \frac{\partial \pi}{\partial H}+\frac{\partial L_{q}}{\partial H}+\frac{\partial L_{f}}{\partial H}\right]}{\left[\frac{\partial C_{h}^{*}}{\partial w_{l}}+\frac{\partial L_{q}}{\partial w_{l}}+\frac{\partial L_{f}}{\partial w_{l}}\right]}>0
$$

All terms in the numerators may be logically assumed to be positive: time for caring for the sick is a normal good, and farm profits and labor supply increase with health. Thus, improvement in health should improve the shadow price of household time and subsequently its welfare state.

(b) Impact on agricultural yield and fuel collection

Totally differentiating (10) and (11), respectively, gives:

$$
\begin{aligned}
& \frac{d Q}{d D}=\frac{\partial Q}{\partial w_{l}} \frac{\partial w_{l}}{\partial D}+\frac{\partial Q}{\partial H} \frac{\partial H}{\partial D}+\frac{\partial Q}{\partial D} \\
& \frac{d F}{d D}=\frac{\partial F}{\partial w_{l}} \frac{\partial w_{l}}{\partial D}+\frac{\partial F}{\partial H} \frac{\partial H}{\partial D}+\frac{\partial F}{\partial D}
\end{aligned}
$$

In (21) and (22), the first terms represent productivity of effects of microdams through their effect on shadow price of time and thus their direction of effect depends on $\frac{\partial W_{l}}{\partial D}$. The first two terms represent changes in the opportunity costs of forgoing work and caring for the sick due to the incidence of waterborne diseases with close proximity to microdams, which cause a change in the shadow wage. The last terms in both (21) and (22) are positive and account for the direct productivity effect of microdams on agricultural production and fuel collection, respectively. The overall sign of $\frac{d Q}{d D}$ and $\frac{d F}{d D}$ depends on the sign of $\frac{\partial W_{l}}{\partial D}$, which we showed above might not be known a priori.

\section{(c) Impact on consumption and health-care expenditures}


Totally differentiate (13) to obtain:

$$
\frac{d C_{j}}{d D}=\frac{\partial C_{j}}{\partial w_{l}} \frac{\partial w_{l}}{\partial D}+\frac{\partial C_{j}}{\partial Y}\left(T-L_{q}-L_{f}-L_{h d}\right) \frac{\partial w_{l}}{\partial D}+\frac{\partial C_{j}}{\partial H} \frac{\partial H}{\partial D}+\frac{\partial C_{j}}{\partial Y} \frac{\partial \pi}{\partial D}
$$

Using the Slutsky equation and the fact that $T=L_{q}+L_{f}$ with incomplete labor market assumption:

$$
\frac{d C_{j}}{d D}=\frac{\partial C_{j}^{*}}{\partial w_{l}} \frac{\partial w_{l}}{\partial D}+\frac{\partial C_{j}}{\partial H} \frac{\partial H}{\partial D}+\frac{\partial C_{j}}{\partial Y} \frac{\partial \pi}{\partial D} ; j=h, m, h c, q, f
$$

In (24), the first term represents compensated price effect and depends on the shadow price of time. The second term shows the health effect, which is negative due to the disease incidence impact of microdams. The third term shows the income effect, which is positive by consumer theory for normal goods. Take, for instance, the case when $j=h$. The first term in (24) shows changes in the opportunity costs of forgoing work and caring for the sick, as a result of changes in the shadow wage of time. Both the second and third terms are positive. ${ }^{8}$ Therefore, the sign of $\frac{d C_{h}}{d D}$ depends on $\frac{\partial W_{l}}{\partial D}$. The direction of the microdam effect on other consumption choices similarly depends on the sign of $\frac{\partial W_{l}}{\partial D}$, which again may not be known a priori.

The comparative static analysis shows that, when the negative health impacts are taken into account, the overall effect on welfare of constructing of irrigation microdams cannot be known a priori. Dams can increase welfare by increasing the production of crops through irrigation opportunities, or through making fuels more available for collection. However, microdams may reduce health, which leads to a decline in welfare as household production decreases either from increased time sick, or increased time required to care for sick family

${ }^{8}$ We assumed that $\frac{\partial C_{h}}{\partial H}<0, \frac{\partial H}{\partial D}<0, \frac{\partial C_{h}}{\partial Y}>0$ and $\frac{\partial \pi}{\partial D}>0$. 
members. Thus the net returns from microdam investment cannot be settled by theoretical analysis alone. In the following we will examine the impact of microdam investment empirically by estimating a household's optimal production and consumption choices.

\section{Empirical Model}

As the theoretical model in section 3 shows, household choice modeling is complicated when input and output markets are incomplete (Singh et al., 1986; Strauss, 1986). In Tigray, households generally use their own labor in most household chores, including fuelwood collection and home healthcare for sick family members. When a well-defined market is nonexistent, an appropriate opportunity cost of time must therefore be constructed. We follow the agricultural household literature and use opportunity cost (shadow wage) for household labor time (e.g., Thornton, 1994; Jacoby, 1993; de Janvry et al., 1991). This requires a joint estimation of production and consumption decisions, rather than a two-stage recursive maximization process that assumes complete markets for inputs and outputs and perfect substitutability between hired and own labor. Before estimating the model parameters, several measurement and econometric issues are addressed.

\section{(a) Measurement Issues}

Tables 1 through 5 present descriptions of data by intervention and control villages as well as for the combined sample. In our data, we have three measures of access to a microdam. These are the distance of each sampled household from the nearest microdam, a dummy variable indicating whether the household is within a 3 kilometer radius of the nearest microdam, and microdam age. All these measures can be reliable indicators of microdam impact on disease incidence and 
household production and consumption decisions. Households nearer to dams will obviously benefit more from increased access to water, but will also become more exposed to waterborne diseases. Microdam age is also important, as older ones have higher forest stocks and more developed water delivery systems.

We have two measures of the health status of the household. The first one is a dummy variable indicating whether any member of the household was suffering from malaria or schistosomiasis infection. As described in section 2, there is a strong correlation between malaria and schistosomiasis incidence and proximity to a microdam. The second variable we use to measure health is the number of days spent sick during one complete cropping season (about a 45 month period). Household health care inputs are measured in terms of time spent caring for the sick and financial costs incurred for medical treatment.

Households produce various crop and vegetable products. A value measure that allows aggregating these agricultural products is used. For instance, agricultural production is measured by multiplying the quantities of various cereals and vegetables in kilograms produced by their respective prices. Similarly, the quantities of fuelwood produced in donkey-loads ${ }^{9}$ are multiplied by their unit price to arrive at a value measure for fuelwood and agricultural residues.

\section{(b) Econometric Issues}

We assume that agricultural yield, fuelwood collection, and health functions have Cobb-Douglas functional forms. The assumption of Cobb-Douglas functions leads to a log-log linear system of input demand and output supply equations. Due to nonseparability between production and consumption decisions in the absence of complete input and output markets, the labor (shadow) wage is endogenous. Following the household literature, we use the value marginal product from

\footnotetext{
${ }^{9}$ A donkey-load is about 25-30 kilograms of firewood.
} 
the agricultural production function to instrument for shadow prices of adult male, adult female and child time (see Jacoby, 1993; Thornton, 1994). We focus primarily on the estimation of profits from agricultural and fuelwood production activities, expenditures on healthcare inputs, household time spent in caring for sick family members, nonfarm income, and adoption of yieldenhancing and resource-conserving agricultural technologies. These are important outcomes in determining the viability of water development projects in disease and drought prone areas.

Finally, our estimated equations will be corrected a priori for heteroskedasticity that might arise from variations among households due to other exogenous characteristics that are unobserved or unrecorded in the data. Heteroskedasticity-corrected and robust Huber/White standard errors will be used instead of the traditional covariance estimates in our hypothesis tests.

\section{Results}

In order to obtain shadow prices of time, agricultural production and fuelwood collection functions were first estimated. ${ }^{10}$ Agricultural yield has significantly benefited from microdam construction-households in the intervention villages have significantly higher production. But sickness has led to a significant reduction in agricultural yield. ${ }^{11}$ Our discussions focus on health outcomes and expenditures, household labor allocations to health care, farm profitability, the level of nonfarm income, and complementary technology adoption decisions.

\footnotetext{
${ }^{10}$ The results are not reported but are available upon request.

${ }^{11}$ Refer to Amacher et al. (2004) for a detailed discussion of the impact of microdams on agricultural yield and fuelwood collection.
} 


\section{(a) Technology Adoption and Microdams}

Since the presence of standing water leads to malaria incidence and a reduction in the health of the population, it may have implications for the adoption of agricultural productivity-enhancing technologies. It may also affect labor-intensive soil conservation investments such as building terraces and bounds, planting multipurpose trees, etc. In this subsection, we examine how proximity to microdam and malaria incidence affect the adoption of agricultural technologies complementary to irrigation.

The empirical evidence presented in Table 6 indicates that households in the intervention villages are more likely to adopt both productivity-enhancing and resource-conserving technologies. But sickness significantly reduces the likelihood of technology adoption. ${ }^{12}$ Households with poor health and high opportunity costs of diverting labor to health-care activities appear less likely to adopt productivity-enhancing as well as resource-conserving technologies. Thus, the positive effect of microdam investment on the adoption of complementary technologies for irrigation agriculture is partially offset by its negative health side effects. Agencies involved in improving the adoption of productivity-enhancing and resource-conserving technologies thus need to emphasize the importance of minimizing the health side effects of new technologies in order to achieve a higher rate of adoption.

\footnotetext{
${ }^{12}$ Time spent sick and not working is an endogenous variable in estimation of the adoption model. We use an instrumental variables (IV) approach and use predicted adult male, adult female and child time sick. The excluded instruments for sick time are respective ages of adult male, adult female and children. IV tests show that age variables are relevant instruments: we fail to reject the hypothesis that they are uncorrelated with the error term and that the second-stage regression is correctly specified (Davidson and MacKinnon, 1993; Bound et al., 1995). Refer to Ersado et al. (2004) for a detailed examination of the links between health and agricultural technology adoption in Tigray.
} 
(b) Health (Illness) Production Function and Microdams

Microdams are feared to increase disease incidence in the study area owing to their favorable effects on waterborne diseases, principally malaria and schistosomiasis. We estimate a function relating time-spent sick to microdam variables important to disease. Table 7 presents the results for the probability of being sick with malaria, and the number of days spent sick for adult male, adult female, and child members of the household. The coefficients estimates on all health variables clearly indicate a strong link between microdams and illness. The intervention village indicator and distance to microdams are positively (negatively) correlated with disease incidence after accounting for altitude as well as annual rainfall levels. Households who live further away from these permanent water dams are significantly less likely to become sick with malaria, and spend significantly less time sick and not working.

(c) The Impact of Microdams on Health-Care Expenditures

Negative health impacts associated with microdams may increase medical expenses for health care, in addition to household time spent caring for the sick and not working. In order to look at this, we estimated a health-care expenditure function using proximity to microdams and other exogenous factors as explanatory variables (see Table 8). Households with closer proximity to microdams spend significantly more money on medical expenses than those further away. Similarly, the incidence of malaria is associated with higher financial health-care costs.

(d) The Impact of Microdams on Household Time 
Another important link between household decisions, microdams, and disease comes from time allocation. In Table 8 we present the results from estimating household time allocation for caring for sick family members. The main objective is to examine the importance of proximity to a microdam in diverting productive labor time to caring for sick family members. Our results confirm that there is a strong positive association between proximity to microdam, malaria incidence, and household time spent caring for the sick. Households in intervention villages tend to use more hired labor, presumably to compensate for time lost because of sickness or caring for sick family members (see Table 8, column 5).

\section{(e) Farm Profitability in the Intervention Villages}

Households in close proximity to irrigation microdams reported higher agricultural productivity. Our empirical estimates of a profit function, which take into account both production input costs, indicate that farm profits are indeed higher in intervention villages (Table 9, column 5). This is despite the fact that we accounted for the productivity costs of time sick and time spent caring for the sick. Thus the current level of microdam investments in Tigray appears welfare enhancing in terms of financial gains from farm activities.

\section{(f) Nonfarm Income and Proximity to Microdams}

A number of studies indicate that diversification into nonfarm income sources constitutes one of the main livelihood strategies that households use for ex ante risk management or to cope ex post with shocks (Rosenzweig and Binswanger, 1993; Reardon et al., 1998; Delgado and Siamwalla, 1999; Barrett et al., 2001). Although the agricultural sector has deservedly received most policy attention in the rural areas of developing countries, rural households sustain their livelihood from 
multiple income sources. There is growing evidence that a significant share of household income comes from nonfarm sources such as off-farm employment, local trading, handicrafts and daily travel to urban employment centers (Ellis, 1998; Reardon et al., 1998). A higher nonfarm income share in rural areas is likely to lessen vulnerability to weather-related shocks, the main risk factor in rural environments where agriculture is the mainstay of livelihood. Thus it would be of interest to examine the implications of microdam investment for income diversification.

Table 9 (column 4) presents the estimates for time allocated for nonfarm activities and the earnings from nonfarm income sources. Labor allocations to off-farm activities and income from nonfarm sources are significantly lower in the intervention villages. This suggests that households in microdam villages have become more vulnerable due not only to deteriorating health but also to shrinking income from nonagricultural sources. Note that, on average, the marginal gains in terms of farm profit are significantly lower than the marginal losses from nonfarm activities. The dams are associated with about a 3 Birr loss from nonfarm sources for every 1 Birr gain in farm profit (see Table 9, columns 4 and 5). This finding is at variance with the expected potential benefit of microdam construction in improving diversification opportunities through making irrigation water available for a wider range of production activities.

\section{Conclusion and Policy Implications}

Agricultural development is a precondition for the wider development of the Ethiopian economy. Despite its centrality in overall growth, the agricultural sector has been underachieving since the late 1960s. Ethiopia's heavy dependence on rainfall for agriculture and food production has led 
to food insecurity, as is evident from the outcomes of recurring droughts. The government of Ethiopia has taken swift measures to increase the productivity and contribution of the agricultural sector to the welfare of rural people and overall economic growth. One of the elements of the agricultural development strategy of the country has been water resource development and utilization in agriculture through the construction of small-scale irrigation dams. However, a critical analysis of the benefits and costs of installing small-scale irrigation dams has been thus far unavailable. This paper examined the potential and significance of installing small-scale irrigation dams to increase agricultural productivity and food production, particularly in areas prone to waterborne diseases. It developed a theoretical framework and provides empirical evidence using recently collected data from Tigray state.

Table 10 presents the marginal benefits and costs associated with the microdam development project in Tigray. The benefits and costs are disaggregated to identify the main ways through which microdams affect and/or contribute to the welfare of households in the project area. ${ }^{13}$ Although the net impact of the microdams on welfare is theoretically ambiguous, the empirical results show that agricultural yield and farm profit have significantly increased in villages with closer proximity to the microdams than in those more distant. However, the ensuing sickness, as the standing pools of water provide an environment conducive for waterborne diseases, has led to significant declines in labor productivity and subsequently depressed the expected returns from water investment. The main health-related costs to the households are via increases in time spent sick and not working, as well as time spent caring for the sick. Disease

\footnotetext{
${ }^{13}$ Note that direct project costs are not included since those costs are not borne by the households directly. Direct project costs are incurred by the government or are covered with support from external sources with no bearing on households themselves.
} 
incidence has also led to a reduction in labor allocation to off-farm activities and a decline in nonfarm income share, thus adversely affecting households' ability to manage and cope with risk. Furthermore, households with poor health and high opportunity costs of diverting labor to health-care activities appear less likely to adopt productivity-enhancing as well as resourceconserving technologies, which are crucial for achieving the ultimate goal of sustainable agricultural development.

The findings underline the importance of weighing beforehand the magnitude of potential economic benefits against the health costs of water development programs. The design and implementation of such programs should strive for greater coordination among economic, environmental and health goals. The overall evidence suggests that carefully designed irrigation dams could significantly improve agricultural production and food security. Even after accounting for health costs in areas where water-related diseases are serious threats such as Tigray, the marginal benefits of investment in water appear to outweigh the costs (see Table 10). ${ }^{14}$ Hence, water development and small-scale irrigation agriculture need to be accorded high priority and institutional support, especially in areas where waterborne diseases are of less concern or can be contained.

\footnotetext{
${ }^{14}$ We should note that this statement is based on efficiency and not equity. Thus, caution should be taken in interpreting the results since our health cost measures fail to capture the pain and suffering associated with the diseases. Other potential costs and concerns, such as the increase in the salinity of the soil in irrigated fields, and sedimentation and the life span of a given microdam, are not taken into consideration as these are beyond the scope of the paper. Accounting for these outcomes would decrease the benefits and more likely increase the costs of microdam investment.
} 


\section{References}

Amacher, G. S., L. Ersado, W. F. Hyde and D. Grebner. 2004. "Disease, microdams and natural resources in Tigray, Ethiopia: Impacts on productivity and labor supplies," Journal of Development Studies, 40(6):122 - 145

Barrett, C.B., T. Reardon and P. Webb. 2001. "Nonfarm income diversification and household livelihood strategies in rural Africa: Concepts, dynamics, and policy implications," Food Policy, 26(4):315-32.

Bound, J., D. A. Jaeger, and R. M. Baker. 1995. "Problems with instrumental variables estimation when the correlation between the instruments and the endogenous explanatory variable is weak," Journal of the American Statistical Association, 90(430):443-50.

Davidson and MacKinnon. 1993. Estimation and Inference in Econometrics. New York: Oxford University Press.

de Janvry, A. M. Fafchamps and E. Sadoulet. 1991. "Peasant household behavior with missing markets: Some paradoxes explained,” Economic Journal 101(409): 1400-417.

Delgado, C. and L. Siamwalla. 1999. "Rural economy and farm diversification developing countries," in Peters, G.H., J. von Braun (eds.), Food Security, Diversification and Resource Management, Refocusing the Role of Agriculture, International Associations of Agricultural Economists, Ashgate, P. 126-43.

Ellis, F. 1998. "Household strategies and rural livelihood diversification," Journal of Development Studies, 35(1): 1-38.

Ersado, L., G. S. Amacher and J. Alwang. 2004. "Productivity and land enhancing technologies in northern Ethiopia: Health, public investments, and sequential adoption," American Journal of Agricultural Economics, 86(2): 321-331 
Ersado, L., G. S. Amacher and J. Alwang. 2001. "Economic analysis of development projects with health side effects: Evidence from northern Ethiopia," International Food Policy Research Institute, Washington, DC.

FAO. 1986. "Highlands reclamation study—Ethiopia," Final Report, Vols I and II, Food and Agriculture Organization of the United Nations, Rome.

FDRE (Federal Democratic Republic of Ethiopia). 2000. “Interim Poverty Reduction Strategy Paper," (International Monetary Fund, Washington, DC).

Grepperud, S. 1996. "Population pressure and land degradation: The case of Ethiopia," Journal of Environmental Economics and Management, (30):18-33.

Grossman, M. 1972. "The demand for health: a theoretical and empirical investigation," NBER, New York.

Haile, T.1988. Causes and Characters of Drought in Ethiopia. Ethiopian Journal of Agricultural Sciences. 10:1-2, 85-97.

Hurni, H. 1993. "Land degradation, famines and resource scenarios in Ethiopia," in D. Pimental (eds.), World Soil Erosion and Conservation, pp. 27-62. Cambridge: Cambridge University Press.

Jacoby, H. 1993. "Shadow wages and peasant family labor supply: An econometric application to the Peruvian Sierra," Review of Economic Studies, 60:903-921.

Lampietti, Julian. 1999. "Do husbands and wives make the same choices? Evidence from northern Ethiopia," Economic Letters, 62: 253-260.

MUC (Mekele University College). 1994. "The impact of land use change on socioeconomic status and incidence of malaria and schistosomiasis in Tigray," A collaborative project proposal by Mekele University College and Tigray Regional Health Bureau. 
Reardon, T., K. Stamoulis, A. Balisacan, M.E. Cruz, J. Berdeue, and B. Banks. 1998. "Rural nonfarm income in developing countries," special chapter in The State of Food and Agriculture 1998, Food and Agriculture Organization of the United Nations, Rome.

Rosenzweig, M and H. Binswanger. 1993. "Wealth, weather risk and the composition and profitability of agricultural investment," Economic Journal, 103:56-78.

Shiferaw B. and S. Holden. 1999. "Soil erosion and smallholders' conservation decisions in the highlands of Ethiopia," World Development, 27(4) 739-752.

Singh, I., L. Squire, and J. Strauss. 1986. “The basic model: Theory, empirical results, and policy conclusions," in I. Singh, L. Squire, and J. Strauss (Eds), Agricultural Household Models, Johns Hopkins University Press, Baltimore, pp. 39-69.

Strauss, J. 1986. “The theory and comparative statics of agricultural household models: A general approach,” in I. Singh, L. Squire, and J. Strauss (Eds), Agricultural Household Models, Johns Hopkins University Press, Baltimore, pp. 71-91.

Thornton, J. 1994. "Estimating the choice behavior of self-employed business proprietors: An application to dairy farming," Southern Economic Journal 87(4):579-95. 
Table 1. Distribution of sampled households by proximity to a microdam

\begin{tabular}{|l|c|c|c|}
\hline \multicolumn{1}{|c|}{ Zone (main town) } & \multicolumn{3}{c|}{ Microdam impact } \\
\hline & Control & Intervention & Total \\
& $\mathrm{N}(\%)$ & $\mathrm{N}(\%)$ & $\mathrm{N}(\%)$ \\
\hline Western Tigray (Shire) & $26(9.7)$ & $102(22.0)$ & $128(17.5)$ \\
\hline Central Tigray (Axum) & $127(47.6)$ & $68(14.7)$ & $195(26.7)$ \\
\hline Central Tigray (Adwa) & $45(16.9)$ & $71(15.3)$ & $116(15.9)$ \\
\hline Southern Tigray (Mekele) & $69(25.8)$ & $222(48.0)$ & $291(39.9)$ \\
\hline Total & $267(100)$ & $463(100)$ & $730(100)$ \\
\hline
\end{tabular}

Table 2. Household characteristics variables not related to microdam

\begin{tabular}{|lccc|}
\hline Variable & $\begin{array}{c}\text { All } \\
\text { Mean }\end{array}$ & $\begin{array}{c}\text { Control } \\
\text { Mean }\end{array}$ & $\begin{array}{c}\text { Intervention } \\
\text { Mean }\end{array}$ \\
\hline Household head age (years) & 47.66 & 48.03 & 47.46 \\
Household head sex (male) & 0.83 & 0.83 & 0.83 \\
Household head education (years) & 0.66 & 0.60 & 0.70 \\
Household size & 5.15 & 5.22 & 5.11 \\
Own landholding (Timad $^{\text {a }}$ ) & 4.69 & 4.65 & 4.71 \\
Number of oxen $_{\text {Number of donkeys }}^{1.36}$ & 1.45 & 1.31 \\
Number of cows & 0.80 & 0.80 & 0.79 \\
Number of sheep & 1.34 & 1.01 & $1.53^{*}$ \\
Number of goat & 0.51 & 0.52 & 0.51 \\
Annual rainfall (millimeters) & 1.39 & 2.03 & $1.02^{*}$ \\
Altitude above sea level (meters) & 722 & 754 & $704^{*}$ \\
\hline
\end{tabular}

*Significant difference at $10 \%$. ${ }^{\text {a }}$ Timad is a traditional measurement unit (1 Timad $\sim 1 / 2$ hectare). 
Table 3. Soil conservation and productivity enhancing technology adoption

\begin{tabular}{|lccc|}
\hline Variable & $\begin{array}{c}\text { All } \\
\text { Mean }\end{array}$ & $\begin{array}{c}\text { Control } \\
\text { Mean }\end{array}$ & $\begin{array}{c}\text { Intervention } \\
\text { Mean }\end{array}$ \\
\hline Eucalyptus trees (number) & 40 & 32 & 45 \\
Neem trees (number) & 0.43 & 0.34 & 0.49 \\
Fertilizer use (cereals, KG) & 28.8 & 32.6 & 26.5 \\
Fertilizer use (vegetables, KG) & 0.09 & 0.00 & 0.14 \\
Use of high yielding varieties (yes) & 0.19 & 0.13 & $0.23^{*}$ \\
Multiple cropping seasons per year (yes) & 0.01 & 0.00 & 0.01 \\
Use of terraces and bunds for soil & & & \\
conservation (yes) & 0.23 & 0.15 & $0.27^{*}$ \\
Irrigation use (yes) & 0.12 & 0.05 & $0.16^{*}$ \\
Use of other agricultural technologies (yes) & 0.05 & 0.00 & $0.08^{*}$ \\
\hline
\end{tabular}

*Significant difference at least at $10 \%$ significance level using unpaired $t$ test.

Table 4. Access, health and labor supply variables

\begin{tabular}{|lccc|}
\hline Variable & $\begin{array}{c}\text { All } \\
\text { Mean }\end{array}$ & $\begin{array}{c}\text { Control } \\
\text { Mean }\end{array}$ & $\begin{array}{c}\text { Intervention } \\
\text { Mean }\end{array}$ \\
\hline Distance to microdam (KM) & 2.60 & -- & 2.60 \\
Distance to drinking water sources (KM) & 1.90 & 2.04 & 1.82 \\
Distance to Market (KM) & 7.91 & 9.28 & 7.13 \\
Distance to health center (KM) & 7.58 & 8.97 & 6.77 \\
Distance own farm land (KM) & 2.16 & 2.11 & 2.19 \\
Distance to fuel wood collection sites (KM) & 11.84 & 6.66 & 14.82 \\
Malaria incidence (yes) & 0.28 & 0.21 & $0.32^{*}$ \\
Total time sick (days) & 28.6 & 23.9 & $31.3^{*}$ \\
Adult female time sick (days) & 15.28 & 12.58 & $16.84^{*}$ \\
Adult male time sick (days) & 10.27 & 7.29 & $11.98^{*}$ \\
Child time sick (days) & 3.04 & 4.02 & 2.47 \\
Household time for care of sick (days) & 2.0 & 1.8 & 2.1 \\
Female time taking care of sick (days) & 1.18 & 1.25 & 1.14 \\
Male time taking care of sick (days) & 0.83 & 0.54 & $1.00^{*}$ \\
Total off farm wage labor (Eth. Birr) & 12.7 & 22.2 & $7.3^{*}$ \\
Total hired labor used (persondays ${ }^{\mathrm{a}}$ ) & 10.1 & 5.2 & $12.9^{*}$ \\
Own total female labor (persondays) & 117.2 & 120.9 & 115.1 \\
Own total male labor (persondays) & 72.4 & 76.4 & 70.1 \\
Child labor (persondays) & 76.1 & 85.7 & $70.6^{*}$ \\
Total household labor supply (persondays) & 188.4 & 196.0 & 184.1 \\
\hline
\end{tabular}

*Significant difference at least at $10 \%$ significance level using unpaired $t$ test.. ${ }^{a} 1$ personday is equivalent to 8 hours work per workday. 
Table 5. Household income and expenditures in intervention and control villages

\begin{tabular}{|cccc|}
\hline Income/Expenditure & All & Control & Intervention \\
Household total income ${ }^{a}$ & Mean & Mean & Mean \\
Income from cereal production $^{\text {Income from vegetable production }}$ & 772 & 1050 & 1080 \\
Income from fuelwood collection & 90 & 696 & $816^{*}$ \\
Income from agricultural residue & 69 & 19 & 15 \\
Income from non-farm sources & 54 & 87 & 84 \\
Income from all other sources & 63 & 63 & 58 \\
Household total expenditures & 854 & 807 & 49 \\
Expenditures on cereals consumption & 150 & 177 & 69 \\
Expenditures on vegetables consumption & 92 & 90 & 981 \\
Expenditures on other food items & 113 & 108 & 116 \\
Expenditures on healthcare & 20 & 14 & $23 *$ \\
Expenditures on energy, fire wood & 36 & 31 & 39 \\
Expenditures on agricultural tools & 72 & 25 & 100 \\
Expenditure on hired labor & 85 & 34 & $115^{*}$ \\
Expenditure on all other categories & 370 & 356 & 377 \\
\hline
\end{tabular}

*Significant difference at least at $10 \%$ significance level using unpaired $t$ test. ${ }^{a}$ measured in Ethiopian Birr (I USD 8.5 Birr). 
Table 6. Yield enhancing (YE) and Resource conserving (RC) technologies adoption

\begin{tabular}{|c|c|c|c|}
\hline Explanatory Variables & YE & $\mathrm{RC}$ & Both \\
\hline Intervention village dummy & $\begin{array}{l}-0.629 \\
(1.5)\end{array}$ & $\begin{array}{l}1.285 \\
(3.5)^{* * *}\end{array}$ & $\begin{array}{l}1.492 \\
(2.1)^{* *}\end{array}$ \\
\hline Shadow wage, male time & $\begin{array}{l}-0.018 \\
(2.0)^{*}\end{array}$ & $\begin{array}{l}-0.014 \\
(1.4)\end{array}$ & $\begin{array}{l}-0.006 \\
(0.5)\end{array}$ \\
\hline Shadow wage, female time & $\begin{array}{l}-0.048 \\
(1.6)\end{array}$ & $\begin{array}{l}-0.033 \\
(1.1)\end{array}$ & $\begin{array}{l}-0.017 \\
(0.6)\end{array}$ \\
\hline Shadow wage, child time & $\begin{array}{l}0.000 \\
(0.1)\end{array}$ & $\begin{array}{l}-0.013 \\
(2.0)^{* *}\end{array}$ & $\begin{array}{l}-0.005 \\
(0.8)\end{array}$ \\
\hline Adult male time sick & $\begin{array}{l}0.003 \\
(0.1)\end{array}$ & $\begin{array}{l}-0.038 \\
(2.1)^{* *}\end{array}$ & $\begin{array}{l}-0.089 \\
(2.3)^{* *}\end{array}$ \\
\hline Adult female time sick & $\begin{array}{l}0.078 \\
(4.4)^{* * *}\end{array}$ & $\begin{array}{l}0.028 \\
(1.9)^{*}\end{array}$ & $\begin{array}{l}0.101 \\
(3.5)^{* * * *}\end{array}$ \\
\hline Child time sick & $\begin{array}{l}-0.157 \\
(4.8)^{* * *}\end{array}$ & $\begin{array}{l}-0.002 \\
(0.1)\end{array}$ & $\begin{array}{l}-0.087 \\
(3.2)^{* * *}\end{array}$ \\
\hline Rental land holding & $\begin{array}{l}0.353 \\
(3.6)^{* * *}\end{array}$ & $\begin{array}{l}0.143 \\
(2.0)^{*}\end{array}$ & $\begin{array}{l}0.431 \\
(3.5)^{* * *}\end{array}$ \\
\hline Own land holding & $\begin{array}{l}0.315 \\
(3.4)^{* * *}\end{array}$ & $\begin{array}{l}0.099 \\
(1.4)\end{array}$ & $\begin{array}{l}0.325 \\
(3.4)^{* * *}\end{array}$ \\
\hline Cereal price & $\begin{array}{l}0.947 \\
(0.6)\end{array}$ & $\begin{array}{l}0.367 \\
(0.3)\end{array}$ & $\begin{array}{l}0.153 \\
(0.1)\end{array}$ \\
\hline Vegetable price & $\begin{array}{l}0.261 \\
(0.3)\end{array}$ & $\begin{array}{l}-3.209 \\
(3.2)^{* * * *}\end{array}$ & $\begin{array}{l}-6.213 \\
(5.7)^{* * *}\end{array}$ \\
\hline Fuelwood price & $\begin{array}{l}0.070 \\
(0.2)\end{array}$ & $\begin{array}{l}0.064 \\
(0.1)\end{array}$ & $\begin{array}{l}1.785 \\
(2.0)^{* *}\end{array}$ \\
\hline Agricultural residue price & $\begin{array}{l}-0.449 \\
(1.4)\end{array}$ & $\begin{array}{l}0.217 \\
(0.4)\end{array}$ & $\begin{array}{l}-0.863 \\
(1.5)\end{array}$ \\
\hline Household size & $\begin{array}{l}-0.068 \\
(0.2)\end{array}$ & $\begin{array}{l}-0.086 \\
(0.2)\end{array}$ & $\begin{array}{l}0.553 \\
(1.1)\end{array}$ \\
\hline Distance to microdam & $\begin{array}{l}-0.593 \\
(1.6)\end{array}$ & $\begin{array}{l}1.198 \\
(4.0)^{* * *}\end{array}$ & $\begin{array}{l}0.903 \\
(1.8)^{*}\end{array}$ \\
\hline Distance to domestic water source & $\begin{array}{l}-1.208 \\
(2.3)^{* *}\end{array}$ & $\begin{array}{l}-1.406 \\
(4.4)^{* * *}\end{array}$ & $\begin{array}{l}-0.609 \\
(1.6)\end{array}$ \\
\hline Distance to health center & $\begin{array}{l}0.726 \\
(1.6)\end{array}$ & $\begin{array}{l}1.644 \\
(2.9)^{* * *}\end{array}$ & $\begin{array}{l}1.686 \\
(3.9)^{* * *}\end{array}$ \\
\hline Microdam age & $\begin{array}{l}0.380 \\
(0.6)\end{array}$ & $\begin{array}{l}-0.551 \\
(0.6)\end{array}$ & $\begin{array}{l}-0.388 \\
(0.3)\end{array}$ \\
\hline Annual precipitation & $\begin{array}{l}7.319 \\
(3.0)^{* * *}\end{array}$ & $\begin{array}{l}-1.263 \\
(0.6)\end{array}$ & $\begin{array}{l}4.393 \\
(1.6)\end{array}$ \\
\hline Altitude above sea level & $\begin{array}{l}-3.988 \\
(0.9)\end{array}$ & $\begin{array}{l}-14.467 \\
(2.2)^{* *}\end{array}$ & $\begin{array}{l}-21.460 \\
(2.0)^{* *}\end{array}$ \\
\hline Constant & $\begin{array}{l}-25.856 \\
(0.8)\end{array}$ & $\begin{array}{l}116.769 \\
(2.3)^{* *}\end{array}$ & $\begin{array}{l}128.352 \\
(1.6)\end{array}$ \\
\hline Observations & 718 & 718 & 718 \\
\hline
\end{tabular}

Note: Robust t statistics in parentheses; * significant at $10 \% ; * *$ significant at $5 \% ; * * *$ significant at $1 \%$. 
Table 7. Health function

\begin{tabular}{|c|c|c|c|c|c|}
\hline Explanatory Variables & $\begin{array}{c}\text { (1) } \\
\text { Probability } \\
\text { of malaria } \\
\text { infection }\end{array}$ & $\begin{array}{c}(2) \\
\text { Adult } \\
\text { male time } \\
\text { sick }\end{array}$ & $\begin{array}{c}(3) \\
\text { Adult } \\
\text { Female } \\
\text { time sick }\end{array}$ & $\begin{array}{c}(4) \\
\text { Children } \\
\text { time sick }\end{array}$ & $\begin{array}{c}(5) \\
\text { Total } \\
\text { time sick }\end{array}$ \\
\hline Intervention village dummy & $\begin{array}{l}0.467 \\
(3.2)^{* * *}\end{array}$ & $\begin{array}{l}0.367 \\
(3.2)^{* * *}\end{array}$ & $\begin{array}{l}0.256 \\
(1.9)^{*}\end{array}$ & $\begin{array}{l}-0.082 \\
(0.9)\end{array}$ & $\begin{array}{l}0.398 \\
(2.7) * * *\end{array}$ \\
\hline Household size & $\begin{array}{l}0.458 \\
(2.8)^{* * *}\end{array}$ & $\begin{array}{l}0.241 \\
(1.8)^{*}\end{array}$ & $\begin{array}{l}0.045 \\
(0.3)\end{array}$ & $\begin{array}{l}0.384 \\
(4.6)^{* * *}\end{array}$ & $\begin{array}{l}0.233 \\
(1.4)\end{array}$ \\
\hline Distance to microdam & $\begin{array}{l}-0.599 \\
(5.1)^{* * *}\end{array}$ & $\begin{array}{l}-0.315 \\
(3.5) * * *\end{array}$ & $\begin{array}{l}-0.071 \\
(0.7)\end{array}$ & $\begin{array}{l}-0.266 \\
(3.6) * * *\end{array}$ & $\begin{array}{l}-0.198 \\
(1.7)^{*}\end{array}$ \\
\hline Distance to drinking water source & $\begin{array}{l}0.079 \\
(0.5)\end{array}$ & $\begin{array}{l}-0.058 \\
(0.5)\end{array}$ & $\begin{array}{l}-0.043 \\
(0.3)\end{array}$ & $\begin{array}{l}0.040 \\
(0.5)\end{array}$ & $\begin{array}{l}-0.182 \\
(1.3)\end{array}$ \\
\hline Distance to health center & $\begin{array}{l}0.594 \\
(4.0)^{* * *}\end{array}$ & $\begin{array}{l}0.380 \\
(3.4)^{* * *}\end{array}$ & $\begin{array}{l}0.194 \\
(1.5)\end{array}$ & $\begin{array}{l}0.268 \\
(3.8)^{* * *}\end{array}$ & $\begin{array}{l}0.425 \\
(2.9)^{* * *}\end{array}$ \\
\hline Microdam age & $\begin{array}{l}-1.061 \\
(6.1)^{* * *}\end{array}$ & $\begin{array}{l}-0.784 \\
(5.5)^{* * *}\end{array}$ & $\begin{array}{l}-0.732 \\
(4.4)^{* * *}\end{array}$ & $\begin{array}{l}-0.510 \\
(5.6)^{* * *}\end{array}$ & $\begin{array}{l}-1.083 \\
(6.2)^{* * *}\end{array}$ \\
\hline Annual precipitation & $\begin{array}{l}3.738 \\
(8.7)^{* * *}\end{array}$ & $\begin{array}{l}2.518 \\
(7.4)^{* * *}\end{array}$ & $\begin{array}{l}2.610 \\
(6.4)^{* * *}\end{array}$ & $\begin{array}{l}1.031 \\
(4.5)^{* * *}\end{array}$ & $\begin{array}{l}3.526 \\
(8.0) * * *\end{array}$ \\
\hline Altitude above sea level & $\begin{array}{l}-10.605 \\
(8.5)^{* * *}\end{array}$ & $\begin{array}{l}-7.455 \\
(8.0)^{* * *}\end{array}$ & $\begin{array}{l}-4.618 \\
(4.1)^{* * *}\end{array}$ & $\begin{array}{l}-4.755 \\
(5.6)^{* * *}\end{array}$ & $\begin{array}{l}-7.990 \\
(7.4)^{* * *}\end{array}$ \\
\hline $\begin{array}{l}\text { Quality of house construction } \\
\text { material }(1=\text { poor, } 3=\text { best })\end{array}$ & $\begin{array}{l}-0.004 \\
(0.0)\end{array}$ & $\begin{array}{l}0.117 \\
(1.1)\end{array}$ & $\begin{array}{l}0.085 \\
(0.6)\end{array}$ & $\begin{array}{l}0.040 \\
(0.5)\end{array}$ & $\begin{array}{l}0.125 \\
(0.9)\end{array}$ \\
\hline House size $(1=$ large, $3=$ small $)$ & $\begin{array}{l}-0.029 \\
(0.3)\end{array}$ & $\begin{array}{l}0.111 \\
(1.6)\end{array}$ & $\begin{array}{l}0.002 \\
(0.0)\end{array}$ & $\begin{array}{l}0.085 \\
(2.0)^{*}\end{array}$ & $\begin{array}{l}0.135 \\
(1.5)\end{array}$ \\
\hline Constant & $\begin{array}{l}56.165 \\
(5.7)^{* * *}\end{array}$ & $\begin{array}{l}41.510 \\
(5.1)^{* * *}\end{array}$ & $\begin{array}{l}19.994 \\
(2.1)^{* *}\end{array}$ & $\begin{array}{l}29.774 \\
(4.4)^{* * *}\end{array}$ & $\begin{array}{l}40.082 \\
(4.1)^{* * *}\end{array}$ \\
\hline Observations & 718 & 717 & 718 & 716 & 716 \\
\hline R-squared & 0.57 & 0.53 & 0.33 & 0.46 & 0.42 \\
\hline
\end{tabular}

Note: Robust t statistics in parentheses; * significant at 10\%; ** significant at 5\%; *** significant at $1 \%$. 
Table 8. Healthcare expenses, time spent caring for sick family members, and hired labor time used for agricultural activities

\begin{tabular}{|c|c|c|c|c|c|}
\hline Explanatory Variables & $\begin{array}{c}\text { (1) } \\
\text { Health } \\
\text { expenses }\end{array}$ & $\begin{array}{c}(2) \\
\text { Male } \\
\text { care time }\end{array}$ & $\begin{array}{c}(3) \\
\text { Female } \\
\text { care time }\end{array}$ & $\begin{array}{c}(4) \\
\text { Total } \\
\text { care time }\end{array}$ & $\begin{array}{c}(5) \\
\text { Hired } \\
\text { labor }\end{array}$ \\
\hline Intervention village dummy & $\begin{array}{c}0.402 \\
(2.8)^{* * *}\end{array}$ & $\begin{array}{l}0.097 \\
(1.8)^{*}\end{array}$ & $\begin{array}{c}0.036 \\
(0.6)\end{array}$ & $\begin{array}{c}0.037 \\
(0.5)\end{array}$ & $\begin{array}{c}0.070 \\
(0.6)\end{array}$ \\
\hline Malaria dummy & $\begin{array}{c}0.748 \\
(4.1)^{* * *}\end{array}$ & $\begin{array}{c}0.051 \\
(0.7)\end{array}$ & $\begin{array}{l}0.155 \\
(1.9)^{*}\end{array}$ & $\begin{array}{l}0.187 \\
(1.9)^{*}\end{array}$ & $\begin{array}{c}0.305 \\
(2.0)^{* *}\end{array}$ \\
\hline Shadow wage, male time & $\begin{array}{c}-0.019 \\
(0.3)\end{array}$ & $\begin{array}{l}-0.034 \\
(1.9)^{*}\end{array}$ & $\begin{array}{l}-0.034 \\
(1.7)^{*}\end{array}$ & $\begin{array}{l}-0.040 \\
(1.7)^{*}\end{array}$ & $\begin{array}{c}0.287 \\
(6.2)^{* * *}\end{array}$ \\
\hline Shadow wage, female time & $\begin{array}{c}0.055 \\
(1.1)\end{array}$ & $\begin{array}{l}0.020 \\
(1.6)\end{array}$ & $\begin{array}{c}-0.014 \\
(0.9)\end{array}$ & $\begin{array}{c}-0.017 \\
(0.9)\end{array}$ & $\begin{array}{c}0.065 \\
(1.9)^{*}\end{array}$ \\
\hline Shadow wage, child time & $\begin{array}{l}0.007 \\
(0.2)\end{array}$ & $\begin{array}{c}-0.012 \\
(0.7)\end{array}$ & $\begin{array}{c}0.012 \\
(0.6)\end{array}$ & $\begin{array}{l}0.013 \\
(0.6)\end{array}$ & $\begin{array}{c}0.183 \\
(5.3)^{* * *}\end{array}$ \\
\hline Cereal price & $\begin{array}{c}0.141 \\
(0.3)\end{array}$ & $\begin{array}{c}-0.022 \\
(0.1)\end{array}$ & $\begin{array}{c}-0.330 \\
(1.6)\end{array}$ & $\begin{array}{c}-0.403 \\
(1.6)\end{array}$ & $\begin{array}{l}0.698 \\
(1.9)^{*}\end{array}$ \\
\hline Vegetable price & $\begin{array}{c}-0.031 \\
(0.1)\end{array}$ & $\begin{array}{l}0.007 \\
(0.0)\end{array}$ & $\begin{array}{c}-0.124 \\
(0.9)\end{array}$ & $\begin{array}{c}-0.163 \\
(1.0)\end{array}$ & $\begin{array}{c}0.168 \\
(0.5)\end{array}$ \\
\hline Fuelwood price & $\begin{array}{c}0.734 \\
(3.4)^{* * *}\end{array}$ & $\begin{array}{c}-0.094 \\
(1.6)\end{array}$ & $\begin{array}{c}-0.093 \\
(0.9)\end{array}$ & $\begin{array}{c}-0.111 \\
(0.9)\end{array}$ & $\begin{array}{l}-0.304 \\
(1.9)^{*}\end{array}$ \\
\hline Agricultural residue price & $\begin{array}{c}0.219 \\
(1.1)\end{array}$ & $\begin{array}{l}-0.172 \\
(1.7)^{*}\end{array}$ & $\begin{array}{l}0.012 \\
(0.2)\end{array}$ & $\begin{array}{l}0.009 \\
(0.1)\end{array}$ & $\begin{array}{c}-0.010 \\
(0.1)\end{array}$ \\
\hline Household size & $\begin{array}{c}0.399 \\
(2.5)^{* *}\end{array}$ & $\begin{array}{c}-0.059 \\
(1.0)\end{array}$ & $\begin{array}{l}0.065 \\
(1.0)\end{array}$ & $\begin{array}{l}0.083 \\
(1.1)\end{array}$ & $\begin{array}{l}0.220 \\
(1.7)^{*}\end{array}$ \\
\hline Distance to microdam & $\begin{array}{c}0.262 \\
(2.2)^{* *}\end{array}$ & $\begin{array}{l}0.037 \\
(0.8)\end{array}$ & $\begin{array}{c}0.124 \\
(2.8)^{* * *}\end{array}$ & $\begin{array}{c}0.156 \\
(2.9)^{* * *}\end{array}$ & $\begin{array}{l}0.029 \\
(0.3)\end{array}$ \\
\hline Distance to drinking water sources & $\begin{array}{c}-0.524 \\
(3.5)^{* * *}\end{array}$ & $\begin{array}{c}0.088 \\
(2.1)^{* *}\end{array}$ & $\begin{array}{c}-0.022 \\
(0.4)\end{array}$ & $\begin{array}{c}-0.023 \\
(0.4)\end{array}$ & $\begin{array}{c}0.071 \\
(0.6)\end{array}$ \\
\hline Distance to health center & $\begin{array}{l}0.268 \\
(1.9)^{*}\end{array}$ & $\begin{array}{l}0.071 \\
(1.7)^{*}\end{array}$ & $\begin{array}{l}0.088 \\
(1.7)^{*}\end{array}$ & $\begin{array}{l}0.106 \\
(1.7)^{*}\end{array}$ & $\begin{array}{l}-0.292 \\
(2.3)^{* *}\end{array}$ \\
\hline Household income & $\begin{array}{c}0.026 \\
(0.5)\end{array}$ & $\begin{array}{c}0.034 \\
(2.7)^{* * *}\end{array}$ & $\begin{array}{l}0.021 \\
(2.0)^{*}\end{array}$ & $\begin{array}{c}0.028 \\
(2.1)^{* *}\end{array}$ & $\begin{array}{c}0.135 \\
(2.8)^{* * * *}\end{array}$ \\
\hline Microdam age & $\begin{array}{c}-1.150 \\
(5.9)^{* * *}\end{array}$ & $\begin{array}{l}-0.106 \\
(2.1)^{* *}\end{array}$ & $\begin{array}{l}-0.112 \\
(1.9)^{*}\end{array}$ & $\begin{array}{l}-0.154 \\
(2.1)^{* *}\end{array}$ & $\begin{array}{c}-0.441 \\
(2.9)^{* * *}\end{array}$ \\
\hline Annual precipitation & $\begin{array}{c}2.487 \\
(5.6)^{* * *}\end{array}$ & $\begin{array}{l}0.048 \\
(0.3)\end{array}$ & $\begin{array}{c}-0.261 \\
(1.4)\end{array}$ & $\begin{array}{c}-0.371 \\
(1.6)\end{array}$ & $\begin{array}{l}-0.902 \\
(2.4)^{* *}\end{array}$ \\
\hline Altitude above sea level & $\begin{array}{c}-7.413 \\
(4.6)^{* * *}\end{array}$ & $\begin{array}{c}-0.033 \\
(0.1)\end{array}$ & $\begin{array}{c}0.529 \\
(0.8)\end{array}$ & $\begin{array}{c}0.552 \\
(0.7)\end{array}$ & $\begin{array}{l}-2.686 \\
(2.1)^{* *}\end{array}$ \\
\hline Constant & $\begin{array}{c}39.162 \\
(3.3)^{* * *}\end{array}$ & $\begin{array}{l}0.560 \\
(0.2)\end{array}$ & $\begin{array}{c}-1.957 \\
(0.4)\end{array}$ & $\begin{array}{c}-1.299 \\
(0.2)\end{array}$ & $\begin{array}{c}26.153 \\
(2.7)^{* * *}\end{array}$ \\
\hline Observations & 715 & 718 & 718 & 718 & 718 \\
\hline R-squared & 0.44 & 0.36 & 0.35 & 0.45 & 0.46 \\
\hline
\end{tabular}

Note: Robust t statistics in parentheses; * significant at 10\%; ** significant at 5\%; *** significant at $1 \%$. 
Table 9. Farm profits, off-farm labor supply and nonfarm income

\begin{tabular}{|c|c|c|c|c|c|}
\hline Explanatory Variables & $\begin{array}{c}\text { (1) } \\
\text { Farm } \\
\text { profits }\end{array}$ & $\begin{array}{c}(2) \\
\text { Male off- } \\
\text { farm } \\
\text { labor }\end{array}$ & $\begin{array}{c}(3) \\
\text { Female } \\
\text { off-farm } \\
\text { labor }\end{array}$ & $\begin{array}{c}(4) \\
\text { Total off- } \\
\text { farm } \\
\text { labor }\end{array}$ & $\begin{array}{c}(5) \\
\text { Total } \\
\text { nonfarm } \\
\text { income }\end{array}$ \\
\hline Intervention village dummy & $\begin{array}{c}0.337 \\
(2.5)^{* *}\end{array}$ & $\begin{array}{c}-0.225 \\
(1.6)\end{array}$ & $\begin{array}{c}-0.397 \\
(2.9)^{* * *}\end{array}$ & $\begin{array}{l}-0.281 \\
(2.4)^{* *}\end{array}$ & $\begin{array}{c}-0.957 \\
(5.2)^{* * *}\end{array}$ \\
\hline Malaria dummy & $\begin{array}{c}0.004 \\
(0.0)\end{array}$ & $\begin{array}{l}-0.386 \\
(2.2)^{* *}\end{array}$ & $\begin{array}{c}-0.109 \\
(0.6)\end{array}$ & $\begin{array}{l}0.085 \\
(0.6)\end{array}$ & $\begin{array}{c}-0.133 \\
(0.7)\end{array}$ \\
\hline Shadow wage, male time & $\begin{array}{c}-0.045 \\
(0.7)\end{array}$ & $\begin{array}{c}-0.611 \\
(12.0)^{* * *}\end{array}$ & $\begin{array}{c}0.033 \\
(0.6)\end{array}$ & $\begin{array}{l}-0.208 \\
(3.8)^{* * * *}\end{array}$ & $\begin{array}{c}-0.175 \\
(2.7)^{* * *}\end{array}$ \\
\hline Shadow wage, female time & $\begin{array}{l}0.075 \\
(1.2)\end{array}$ & $\begin{array}{c}0.143 \\
(3.2)^{* * *}\end{array}$ & $\begin{array}{c}-0.456 \\
(8.8)^{* * *}\end{array}$ & $\begin{array}{l}-0.244 \\
(5.6)^{* * *}\end{array}$ & $\begin{array}{c}-0.047 \\
(0.8)\end{array}$ \\
\hline Shadow wage, child time & $\begin{array}{l}0.083 \\
(1.6)\end{array}$ & $\begin{array}{l}0.041 \\
(0.9)\end{array}$ & $\begin{array}{c}0.132 \\
(2.8)^{* * *}\end{array}$ & $\begin{array}{c}0.110 \\
(3.1)^{* * *}\end{array}$ & $\begin{array}{l}0.003 \\
(0.1)\end{array}$ \\
\hline Cereal price & $\begin{array}{l}0.147 \\
(0.3)\end{array}$ & $\begin{array}{c}-2.789 \\
(5.6)^{* * *}\end{array}$ & $\begin{array}{l}0.697 \\
(1.4)\end{array}$ & $\begin{array}{c}-0.397 \\
(0.9)\end{array}$ & $\begin{array}{c}-2.444 \\
(4.0) * * *\end{array}$ \\
\hline Vegetable price & $\begin{array}{l}0.475 \\
(1.3)\end{array}$ & $\begin{array}{c}1.507 \\
(3.4)^{* * *}\end{array}$ & $\begin{array}{c}-0.699 \\
(1.5)\end{array}$ & $\begin{array}{c}-0.134 \\
(0.4)\end{array}$ & $\begin{array}{c}1.360 \\
(2.7)^{* * * *}\end{array}$ \\
\hline Fuelwood price & $\begin{array}{c}-0.044 \\
(0.2)\end{array}$ & $\begin{array}{l}0.049 \\
(0.2)\end{array}$ & $\begin{array}{l}-0.724 \\
(2.7)^{* * *}\end{array}$ & $\begin{array}{l}-0.468 \\
(1.8)^{*}\end{array}$ & $\begin{array}{l}-0.661 \\
(2.4)^{* *}\end{array}$ \\
\hline Agricultural residue price & $\begin{array}{l}0.124 \\
(0.8)\end{array}$ & $\begin{array}{l}-0.390 \\
(1.9)^{*}\end{array}$ & $\begin{array}{l}-0.592 \\
(3.9)^{* * * *}\end{array}$ & $\begin{array}{c}-0.537 \\
(3.9)^{* * *}\end{array}$ & $\begin{array}{c}-0.249 \\
(1.3)\end{array}$ \\
\hline Household size & $\begin{array}{c}0.751 \\
(3.8)^{* * *}\end{array}$ & $\begin{array}{c}0.615 \\
(3.7)^{* * *}\end{array}$ & $\begin{array}{c}1.191 \\
(6.8)^{* * *}\end{array}$ & $\begin{array}{c}0.948 \\
(5.7)^{* * * *}\end{array}$ & $\begin{array}{l}0.188 \\
(0.9)\end{array}$ \\
\hline Distance to microdam & $\begin{array}{l}0.157 \\
(1.1)\end{array}$ & $\begin{array}{c}0.438 \\
(3.2)^{* * *}\end{array}$ & $\begin{array}{c}0.722 \\
(5.6)^{* * *}\end{array}$ & $\begin{array}{c}0.728 \\
(6.3)^{* * *}\end{array}$ & $\begin{array}{l}-0.330 \\
(2.2)^{* *}\end{array}$ \\
\hline Distance to drinking water sources & $\begin{array}{l}0.167 \\
(1.0)\end{array}$ & $\begin{array}{l}-0.267 \\
(1.7)^{*}\end{array}$ & $\begin{array}{c}-0.040 \\
(0.3)\end{array}$ & $\begin{array}{c}-0.104 \\
(0.8)\end{array}$ & $\begin{array}{l}0.141 \\
(0.7)\end{array}$ \\
\hline Distance to health center & $\begin{array}{l}0.314 \\
(1.8)^{*}\end{array}$ & $\begin{array}{l}0.039 \\
(0.3)\end{array}$ & $\begin{array}{l}-0.258 \\
(1.9)^{*}\end{array}$ & $\begin{array}{c}-0.205 \\
(1.6)\end{array}$ & $\begin{array}{l}-0.447 \\
(2.5)^{* *}\end{array}$ \\
\hline Microdam age & $\begin{array}{l}0.339 \\
(1.7)^{*}\end{array}$ & $\begin{array}{c}0.866 \\
(4.1)^{* * * *}\end{array}$ & $\begin{array}{c}1.334 \\
(7.6)^{* * * *}\end{array}$ & $\begin{array}{c}1.205 \\
(7.7)^{* * *}\end{array}$ & $\begin{array}{c}0.777 \\
(2.8)^{* * *}\end{array}$ \\
\hline Annual precipitation & $\begin{array}{c}2.521 \\
(5.3)^{* * *}\end{array}$ & $\begin{array}{c}-1.669 \\
(3.5)^{* * *}\end{array}$ & $\begin{array}{c}-3.670 \\
(7.6)^{* * *}\end{array}$ & $\begin{array}{c}-3.096 \\
(7.4)^{* * *}\end{array}$ & $\begin{array}{c}-2.776 \\
(4.7)^{* * *}\end{array}$ \\
\hline Altitude above sea level & $\begin{array}{c}4.804 \\
(3.1)^{* * *}\end{array}$ & $\begin{array}{c}9.170 \\
(5.7)^{* * * *}\end{array}$ & $\begin{array}{c}15.276 \\
(10.3)^{* * * *}\end{array}$ & $\begin{array}{c}14.263 \\
(10.5)^{* * *}\end{array}$ & $\begin{array}{c}6.669 \\
(3.2)^{* * *}\end{array}$ \\
\hline Constant & $\begin{array}{l}-51.774 \\
(4.6)^{* * *}\end{array}$ & $\begin{array}{l}-57.482 \\
(4.8)^{* * * *}\end{array}$ & $\begin{array}{l}-90.601 \\
(8.4)^{* * *}\end{array}$ & $\begin{array}{l}-85.584 \\
(8.8)^{* * *}\end{array}$ & $\begin{array}{l}-27.923 \\
(1.8)^{*}\end{array}$ \\
\hline Observations & 720 & 720 & 720 & 720 & 717 \\
\hline R-squared & 0.51 & 0.43 & 0.34 & 0.42 & 0.32 \\
\hline
\end{tabular}

Note: Robust $\mathrm{t}$ statistics in parentheses; * significant at $10 \%$; ${ }^{* *}$ significant at $5 \%$; ${ }^{* *}$ significant at $1 \%$. 
Table 10. Estimates of marginal benefits and costs per unit (KM) proximity to a nearest microdam

\begin{tabular}{|c|c|}
\hline Benefits/Costs (in Birr) & \multicolumn{1}{|c|}{ Estimated Value } \\
\hline Marginal Benefits & $\mathbf{5 3 . 2 5}$ \\
\hline Improved yield & 19.25 \\
\hline Firewood collection & 9.80 \\
\hline Forest stock & 6.90 \\
\hline Interaction & 17.30 \\
\hline Marginal Costs & $\mathbf{1 8 . 9 8}$ \\
\hline Cost agricultural land to trees & 0.87 \\
\hline Sick labor and/or caring for sick & 17.42 \\
\hline Financial cost of healthcare & \\
\hline Net Benefit & $\mathbf{2 4 . 2 7}$ \\
\hline
\end{tabular}

Source: adopted from Ersado, et al. 2001. 